\title{
Monitoring of the states of malfunction of the EGR system in TDCi engines fueled with Ekodiesel Ultra and B10 fuel
}

\begin{abstract}
The paper discusses the identification of malfunctions in the EGR system based on a list of OBD II error codes. The authors monitored EGR systems of vehicles fitted with DURATORQ TDCi engines. The Analysis of the processes of heat transfer and mass exchange in the engine intake system drew attention to a number of simplifications in the formal description introducing a wide range of tolerance for the instantaneous recirculation rate. The aim of this study was to determine the influence of diesel oil, Ekodiesel Ultra with biocomponents and B10 fuel used for the fueling of diesel engines on the formation of deposits in the EGR system. The analysis was performed in a laboratory utilizing the methods of energy dispersive $X$-ray fluorescence and infrared spectroscopy.
\end{abstract}

Key words: $E G R$, diagnostic procedures $O B D, X$-ray fluorescence, infrared spectroscopy $I R$

\section{Monitorowanie stanu niesprawności układu EGR silników TDCi zasilanych olejem napędowym Ekodiesel Ultra oraz paliwem B10}

\begin{abstract}
W artykule dokonano analizy procesu uszkodzeń oraz lokalizacji usterek w ukladzie EGR silników DURATORQ TDCi $z$ udokumentowanym procesem eksploatacji, przegladów technicznych i stosowanych rodzajów paliw. Analiza procesu wymiany ciepła i masy na odcinku układu dolotowego silnika zawiera szereg uproszczeń w opisie formalnym wprowadzając szeroki zakres tolerancji chwilowej wartości stopnia recyrkulacji. Wnioskowanie zwrócone zostało na potencjalny wpływ rodzaju paliw, stosowanych w procesie równoległej eksploatacji analizowanych silników na przyczyny powstawania osadów w układzie EGR prowadzacych do występowania zapisanych błędów. Badania porównawcze przeprowadzono z wykorzystaniem oleju napędowego Ekodiesel Ultra oraz paliwa B10 z udziałem biokomponentów. Analizy przeprowadzono $w$ laboratorium akredytowanym $z$ wykorzystaniem metod fluorescencji rentgenowskiej $z$ dyspersja energii oraz spektroskopii w podczerwieni.
\end{abstract}

Słowa kluczowe: system EGR, procedury diagnostyczne OBD II, fluorescencja rentgenowska XRF, spektroskopia IR

\section{Introduction}

The optimization of the process of charge combustion in a multiple injected diesel engine using hydrocarbon and biocomponent fuels in a Common Rail system sets the main trends in the research and development works on diesel engines. A symptom of these modifications is the development of a system allowing homologation compliance with respect to the emission limits, particularly: $\mathrm{CO}, \mathrm{HC}, \mathrm{NO}_{x}$ and particulate matter (PM). Exhaust aftertreatment systems such as exhaust gas recirculation (EGR), catalytic converters and Diesel Particulate Filters (DPF) are used increasingly. Parallel to the advancement of EGR systems for the reduction of the $\mathrm{NO}_{\mathrm{x}}$ concentration engineers introduce SCR systems (Selective Catalytic Reduction) using AdBlue or DEF (Diesel Exhaust Fluid) complying with the quality requirements of the ISO-22241 standard.

Research into innovative processes of exhaust gas catalysis and advancement of the design of DPF filters are convergent with the improvement of the physical chemical characteristics of FAME biofules containing certain selected conditioners $[3,8]$. The research experiments additionally cover selective composition of biofuels with certain selected conditioners. Particulate matter, the result of the fuel combustion is an effect of local incomplete combustion that leads to the formation of carbon and agglomerates of different size.

\section{Wstęp}

Optymalizacja procesu spalania ładunku w silniku o ZS przy wieloetapowym wtrysku paliwa węglowodorowego oraz paliwa z udziałem biokomponentów w systemie Common Rail, wyznacza główne kierunki prac badawczych w zakresie rozwoju silników o ZS. Symptomem tych modyfikacji jest rozwój układów pozwalających zachować zgodność homologacyjną z limitami emisji toksycznych składników spalin, głównie: $\mathrm{CO}, \mathrm{HC}, \mathrm{NO}_{\mathrm{x}}$ oraz cząstek stałych PM (Particulate Matter). Zaznacza się upowszechnienie układów oddziałujących na spaliny silnika (Exhaust Aftertreatment) takich jak recyrkulacja spalin EGR (Exhaust Gas Recirculation), konwertery katalityczne (katalizatorów) a także stosowanie filtrów cząstek stałych DPF (Diesel Particulate Filter). Równolegle z doskonaleniem układów EGR dla potrzeb obniżenia poziomu stężenia $\mathrm{NO}_{\mathrm{x}}$ wprowadzane są układy SCR (Selective Catalytic Reduction) z wykorzystaniem reduktora AdBlue lub DEF (Diesel Exhaust Fluid) spełniających wymogi jakościowe norm ISO-22241.

Badania w zakresie innowacyjnych procesów katalizy spalin wraz z doskonaleniem konstrukcji filtrów cząstek stałych DPF przebiegają równolegle $\mathrm{z}$ doskonaleniem cech fizyko-chemicznych biopaliw FAME z dobranym pakietem dodatków uszlachetniających [3, 8]. Eksperymenty badawcze obejmują ponadto selektywne komponowanie biopaliw 
The manufacturers of diesel engines for modern farm tractors declare the compatibility of their engines with the B100 biofuels provided the EN/PN 14213 quality standard is met. In this case the application of EGR systems is reduced to the benefit of the SCR systems using AdBlue. Sometimes a combined SCR and EGR systems are applied, as is in the case of JOHN DEERE heavy-duty farm tractors.

In diesel engines of passenger vehicles fueled with conventional hydrocarbon fuels with a growing content of FAME we can see an advancement of the EGR systems and the systems controlling their operation, which leads to a reduction of the combustion rate, thus contributing to the reduction of the $\mathrm{NO}_{x}$ concentration in the exhaust gas. As a result of this process the maximum temperature of combustion is reduced along with the amount of oxygen in the charge fed to the cylinder. However, an excess amount of exhaust gas in the charge fed to the cylinder may result in a drop of the engine power and an increase in the emission of $\mathrm{PM}$, thus deteriorating other engine indexes $[1,6]$.

Taking into account the popularity of DPF systems and catalytic converters in diesel engines the condition of a malfunctioning EGR is inadmissible [3].

FAME biofuel is substantially different from diesel fuel in that it has a different chemical constitution, fractional composition, viscosity, molar mass and the content of sulfur and oxygen. The obtainment of a high quality FAME fuel is mainly conditional upon the used resources, preliminary rectification, the course of the transestrification process and the applied pack of conditioners such as antioxidants, depresators and biocides. Additionally, esters should, not contain any remnants of methanol that increases the risk of seizure of the friction pairs in the fuel feed system. The presence of the linoleic and linolenic acids leads to the processes of oxidation and polymerization of fuel. Higher fatty acids have a substantial impact on the operation of DPF because high content of unsaturated acids results in an increase of the emission of soot. Additionally, oils of low quality may contain more contaminants such as free fatty acids, phospholipids, colorants and water [4].

One of the important quality parameters of fuels tightly related to their chemical constitution is the proneness to form deposits in the intake system and combustion chambers. A chemical composition of the fuel also introduces a low thermal stability and susceptibility to polymerization the result of which is sludge formation [4].

\section{Functional analysis of the EGR system}

The total mass of the charge fed to the cylinder is a mixture of air and exhaust gas of varied proportions and is calculated based on such parameters as: engine speed, intake air mass, charging pressure and the temperature of the components. The mass of the recirculated exhaust gas is calculated from the difference of the total mass of the charge and the mass of air in reference to the intake air temperature correction [11]. We can, thus determine the exhaust gas recirculation rate as a ratio of the mass of the exhaust gas to the mass of air and compare this value under given engine load conditions with the value stored in the ECU. The opening wraz z dobranymi pakietami uszlachetniaczy. Cząstki stałe PM powstające w wyniku silnikowego spalania paliw są efektem miejscowego niezupełnego i niecałkowitego spalania paliwa, prowadząc do powstania węgla i tworzenia się aglomeratów o różnej wielkości.

Producenci silników o ZS dla współczesnych ciągników rolniczych deklarują możliwość stosowania biopaliw typu B100 z zastrzeżeniem spełnienia wymogów normy jakościowej EN/PN 14213. W tym przypadku zaznacza się odejście od klasyki stosowania układów EGR na rzecz układów SCR z wykorzystaniem reduktora AdBlue. Niekiedy wprowadza się współdziałanie systemów SCR i EGR jak np. we współczesnej wersji ciężkich ciągników firmy JOHN DEERE.

W przypadku silników o ZS samochodów osobowych zasilanych paliwami węglowodorowymi z postępującym wzrostem udziału FAME zaznacza się doskonalenie układów EGR oraz systemów sterowania pracą układu, prowadząc do obniżenia prędkości spalania, co przyczynia się do spadku poziomu stężenia $\mathrm{NO}_{\mathrm{x}}$ w spalinach. W wyniku tego procesu zostaje obniżona maksymalna temperatura spalania jak również następuje ograniczenie maksymalnej ilość tlenu w ładunku dostarczanym do cylindra. Jednak nadmierny udział spalin w całym ładunku dostarczanym do cylindra może powodować spadek mocy oraz znaczny wzrost emisji cząstek stałych, a przez to uzyskanie niekorzystnych wartości innych wskaźników pracy silnika $[1,6]$.

Biorąc pod uwagę upowszechnienie systemów PDF oraz konwerterów katalitycznych w układzie wylotowym silników z ZS, stan wadliwego działania EGR należy uznać za niedopuszczalny [3].

Biopaliwo FAME wykazuje zasadnicze zróżnicowanie względem ON przede wszystkim ze względu na budowę chemiczną, skład frakcyjny, lepkość, masę molową oraz zawartość siarki i tlenu. Uzyskanie wysokiej jakości paliwa FAME zależy przede wszystkim od użytego surowca, wstępnego oczyszczania, przebiegu procesu transestryfikacji oraz zastosowanego pakietu dodatków uszlachetniających takich jak np. depresatory, antyoksydanty, biocydy. Dodatkowo estry nie powinny zawierać resztek metanolu, który zwiększa ryzyko zatarcia elementów roboczych aparatury paliwowej. Obecność kwasów linolowego i linolenowego prowadzi do procesów utleniania i polimeryzacji biopaliwa. Wyższe kwasy thuszczowe mają znaczący wpływ na pracę DPF, gdyż wysoka zawartość kwasów nienasyconych powoduje wzrost emisji sadzy. Dodatkowo oleje niskiej jakości mogą zawierać więcej zanieczyszczeń, takich jak wolne kwasy tłuszczowe, fosfolipidy, barwniki, wodę [4].

Jednym $\mathrm{z}$ istotnych parametrów jakościowych paliw ściśle związanych z ich budową chemiczną jest skłonność do tworzenia się osadów w układzie dolotowym i komorach spalania. Skład chemiczny paliwa wprowadza również niską stabilność termiczną a także skłonność do polimeryzacji w wyniku czego powstają szlamy[4].

\section{Analiza funkcjonalna układu EGR}

Całkowita masa zasysanego ładunku do cylindra jest mieszaniną powietrza i spalin przy zmiennych proporcjach i jest obliczana na podstawie takich parametrów jak: pręd- 
of the EGR valve defines the mass of the exhaust gas to assure the instantaneous required recirculation rate $\mathrm{X}_{\mathrm{EGR}}$. The error range is precisely determined and its excess results in an emission related malfunction signaled by a MIL.

The identification of DTCs in this case is a complex procedure because a group of combined signals is analyzed that come from the solenoid valve controlling the pneumatic EGR actuator or directly from the electric actuator. The signals are then compared against the signal of the mass airflow rate, the intake pressure, the temperatures of the media and the engine speed. The EGR system is distinguished by a great range of tolerance to momentary change of the recirculation rate, particularly in the interval of non-steady engine operating states.

The thermodynamics-related issues have been presented in the previous publication on a diagnosing procedure of the states of malfunction of the EGR system based on a multi-symptom structure of stored DTCs for the VW group vehicles fitted with 1,9 TDI ASZ having a pneumatic EGR valve positioning actuator EGR [2].

The analysis of the energy balance of heat and mass exchange contains certain simplifications due to a lack of the possibility of unambiguous description of all the factors conditioning an accurate parameterization of the exhaust gas recirculation process.

A fundamental problem is proper determination of the specific heat of the recirculated exhaust gas based on the specific heat of all its individual components. As the engine deterioration advances the share of the fraction of burnt lubricant increases. Besides, as a result of the use of biofuel conditioners there are more (as compared to regular hydrocarbon fuels) such components as: $\mathrm{CO}_{2}, \mathrm{CO}, \mathrm{HC}$ and $\mathrm{NO}_{x}[2]$.

Another approximation of the actual state is contained in the notation of the Clapeyron equation of the state of the formed mixture of air and exhaust gas. There are no effective methods of measurement of the mass flow of the recirculated exhaust gas. A useful parameter is the exhaust gas density under given engine load conditions. The difficulty in the notation also results from the fact that feeding recirculated exhaust gas, irrespective of its prior chilling, results in a growth of the intake air temperature [5].

A secondary temperature drop of the mixture takes place as a result of a heat exchange in the intake manifold. In this case, we need to allow for the area of the heat transfer, the heat transfer coefficient by the material structure of the intake manifold and the duration of the transfer at the temperature difference between the charge and the surroundings.

A different nature of the heat exchange takes place in the portion of the intake manifold located in the cylinder head ending in the valve seat zone. We can precisely determine the flow time of the mixture through the analyzed distance (taking the engine speed and the filling efficiency) but it is difficult to average the medium flow results having variable intake geometry in the zones of varied wall temperatures. A simplification is, thus introduced consisting in that a circular cross section is assumed of the intake manifold for its replace- kość obrotowa wału, masa powietrza zasysanego, ciśnienie doładowania oraz temperatury składników.

Masa recyrkulowanych spalin wyznaczana jest z różnicy masy całkowitej ładunku i masy powietrza w odniesieniu do korekty temperaturowej powietrza zasysanego [11]. Zatem można wyznaczyć stopień recyrkulacji jako stosunek masy spalin do masy powietrza i porównać tą wartość w danych warunkach obciążeń silnika z wartością zapisaną w pamięci sterownika. Stopień otwarcia zaworu EGR wyznacza masę spalin dla potrzeb zapewnienia chwilowej wartości stopnia recyrkulacji $X_{\mathrm{EGR}}$. Przedział błędu jest ściśle ustalony a przekroczenie tej wartości wyznacza usterką emisyjną prowadząc do sygnalizacji stanu pracy silnika poprzez kontrolkę MIL.

Rozpoznanie błędów stanowi w tym przypadku złożoną procedurę, gdyż analizowana jest grupa wzajemnie sprzężonych sygnałów pochodzących z elektrozaworu sterującego siłownikiem pneumatycznym EGR lub wprost z siłownika elektrycznego układu, w odniesieniu do sygnału masowego natężenia przepływu, ciśnienia w układzie dolotowym, temperatur czynników oraz prędkości obrotowej wału. Układ EGR wyróżnia się stopniem znacznego przedziału tolerancji na chwilową zmianę stopnia recyrkulacji, zwłaszcza w przedziale nieustalonych obciążeń silnika.

Zagadnienia termodynamiczne zostały przedstawione $\mathrm{w}$ poprzedniej publikacji dotyczącej procesu diagnozowania stanów awaryjnych układu EGR na podstawie wielosymptomowej struktury zapisanych błędów dla pojazdów grupy VW z silnikami 1,9 TDI ASZ wyposażonych w pneumatyczny siłownik pozycjonujący zawór EGR [2].

Analiza bilansu energetycznego wymiany ciepła i masy zawiera w sobie pewien zakres uproszczeń z uwagi na brak możliwości jednoznacznego opisania wszystkich czynników warunkujących dokładną parametryzację procesu recyrkulacji spalin.

Zasadniczy problem stanowi właściwe określenie ciepła właściwego recyrkulowanych spalin na podstawie ciepła właściwego poszczególnych jego składników. Wraz ze stopniem zużycia silnika zwiększa się udział frakcji spalanego oleju smarującego. Ponadto, w wyniku stosowania dodatków biopaliwowych zaznacza się zróżnicowany, w stosunku do paliw węglowodorowych, udział takich składników jak: $\mathrm{CO}_{2}, \mathrm{CO}, \mathrm{HC}, \mathrm{NO}_{\mathrm{x}}[2]$.

Następne przybliżenie stanu rzeczywistego zawarte jest w zapisie równania Clapeyrona stanu powstałej mieszaniny powietrza i spalin. Zaznacza się brak efektywnych metod pomiaru masowego natężenia przepływu recyrkulowanych spalin. Przydatnym parametrem jest gęstość spalin w danych warunkach obciążeń silnika. Utrudnienie zapisu wynika również z faktu, iż doprowadzenie recyrkulowanych spalin, niezależnie od możliwości ich wcześniejszego ochłodzenia, powoduje wzrost temperatury zasysanego powietrza [5].

Ponadto dochodzi do wtórnego spadku temperatury mieszaniny w wyniku oddawania ciepła do struktury kolektora dolotowego. Należy w tym przypadku uwzględnić powierzchnię wymiany ciepła, współczynnik przenikania ciepła przez strukturę materiałową kolektora ssącego oraz 
ment diameter, which leads to a simplification of the notation of the heat exchange area. The situation is aggravated by the fact that, due to tar deposits, there is no possibility of allowing for the variable flow resistance of the exhaust gas in the zone of the valve controlling the exhaust gas flow [2].

The functional condition of an EGR system can be improved by introducing a variety of signal converters in the design of the intake and exhaust systems of an engine, which leads to a complication of the system, a modification of the ECU software and an increase in the overall costs.

\section{EGR system diagnostic}

The fundamental objective of on-board diagnostic in the OBD II standard is the control of the exhaust emissions with respect to the currently applicable emission limits of EURO IV and $\mathrm{V}$. The area of the unification of the diagnostic principles has been significantly extended by compliance of the controllers with the software according to the OBD II system meeting both the SAEJ1830 and ISO9141-2 standards. The coexistence of the diagnostic controllers was initiated when the ISO15031-3 standard was introduced allowing communication through the CAN standard (Controller Area Network) [7].

The skill of making multisymptom diagnostic conclusions and the knowledge of technical solutions used in the functional system of a vehicle are a basis for the formulation of correct diagnostic decisions [2].

A facilitating element is the unification of the nomenclature of the systems and their components (SAE J1930) as well as the unification and location of the DLC (Data Link Connector) according to SAE J1962. An important step in the development of OBD was the notation and definitions of the trouble codes (SAE J2012). The storage of an error code in the controller memory was supplemented with the storage of the operating parameters at which the error occurred, thus creating a database (Freeze Frame). The pulling of the error codes from the controller is possible with a scan tool. Diagnostic scan tools (SAE J1978) and the description of the individual scan tool operating modes (SAE J1979) are also subject to standardization. The principle of error code hierarchy was introduced not only because of the component or a functional system malfunction but mainly to maintain the exhaust emissions on the level below the admissible values. An incorrect course of the combustion process or a faulty operation of the system elements results in a flash of a MIL light (Malfunction Indicator Light) [12].

A list of standardized error codes directly or indirectly related to the operation of the EGR systems has been shown in Table 1.

Besides, the P0100 to P0104 error codes shown in table 1 may provide additional information in the assessment of the EGR system operation (showing an incorrect recirculation rate). The stored error codes from the P0110 to P0114 group are assigned to the air intake temperature sensor. Usually problematic in the malfunction identification is the effect of simultaneous storage of the error codes in the turbocharger pressure circuit from the P0235 to P0242 group supplemented with the error code of the recirculated exhaust gas temperature sensor from the P0544 to P0549 group. czas wymiany ciepła przy różnicy temperatur ładunku i otoczenia.

Odmienny charakter wymiany ciepła zaznacza się na odcinku kanału ssącego zlokalizowanego w głowicy, kończąc na strefie gniazda zaworu ssącego. O ile można w dokładny sposób wyznaczyć czas przepływu mieszaniny na analizowanym odcinku, biorąc za podstawę prędkość obrotową wału i sprawność napełnienia, to jednak trudno jest uśrednić warunki przepływu czynnika przy zmiennej geometrii kanału w strefach o zróżnicowanych temperaturach ścianek. Zatem wprowadza się uproszczenie polegające na przyjęciu kołowego przekroju kanału dla zastępczej jego średnicy, co prowadzi do uproszczenia zapisu powierzchni wymiany ciepła. Sytuację pogarsza fakt braku możliwości uwzględnienia zmiennych oporów przepływu spalin w strefie zaworu sterującego przepływem spalin w wyniku zalegania nagaru [2].

Stan funkcjonalny układu EGR można poprawić wprowadzając szereg przetworników sygnałów w strukturze układu wlotowego i wylotowego silnika, co w prostym odniesieniu prowadzi do zwiększenia stopnia komplikacji układu, konicznej modyfikacji oprogramowania sterownika ECU oraz wzrostu kosztów przedsięwzięcia.

\section{Diagnostyka układu EGR}

Podstawowym celem diagnostyki pokładowej wg standardu OBD II jest kontrola emisji szkodliwych składników spalin odniesiona do obowiązujących obecnie wymogów normatywów EURO IV i V. Obszar unifikacji zasad diagnostyki został znacząco powiększony poprzez zgodność komunikacji sterowników z oprogramowaniem wg standardu OBD II spełniających zarówno wymagania normy SAEJ1830 jak również ISO9141-2. Współdziałanie kontrolerów diagnostycznych zaistniało wraz z zapisem normy ISO15031-3 wprowadzającej możliwość komunikacji za pośrednictwem sieci standardu CAN (Controller Area Network - Sieć Obszaru Sterownika) [7].

Umiejętność wielosymptomowego wnioskowania oraz znajomość rozwiązań technicznych stosowanych w obrębie układów funkcjonalnych pojazdu stanowią podstawę do kształtowania trafnych decyzji diagnostycznych [2].

Ułatwieniem jest wprowadzenie normalizacji nazewnictwa układów oraz ich elementów (SAE J1930), a także unifikacja i lokalizacja złącza diagnostycznego DLC (Data Link Connector) zgodnie z SAE J1962. Ważnym etapem stał się zapis, oznaczenia i definicje kodów usterek (SAE J2012). Rejestracja kodu usterki w pamięci sterownika została uzupełniona zapisem parametrów pracy silnika, przy których wystąpiła usterka tworząc bazę danych (Freeze Frame). Odczytanie kodów usterek zapisanych w pamięci sterownika możliwe jest z wykorzystaniem testera diagnostycznego - skanera (Scan-Tool). Normalizacji podlegają również testery diagnostyczne (SAE J1978) oraz opis poszczególnych trybów pracy skanera (SAE J1979). Zasada hierarchii kodów błędu została wprowadzona nie tylko ze względu na wystąpienie uszkodzenia elementu lub układu funkcjonalnego, lecz przede wszystkim w aspekcie utrzymania emisji szkodliwych składników spalin poniżej wartości dopuszczalnych. Wadliwy przebieg procesu spalania lub 
A diagnostic monitor contains diagnostic procedures responsible for controlling and observation of the components assigned to it. According to the OBD principles each controller of a vehicle has at least one control procedure implemented that creates continuous and non-continuous monitors. The engine manufacturers are obliged to publish the algorithm allowing the realization of a driving cycle that guarantees the realization of all EOBD/OBD II monitors [9].

\section{EGR system diagnostics using a scan tool}

The subject of the analysis as regards the identification of malfunctions in the EGR system is the intake manifold of a Common Rail DURATORQ TDCi engine fitted in FORD MONDEO MK4. The intake system is fitted with a variable geometry turbocharger and an intercooler. The ECU controller - J248 controls the stepper motor positioning the EGR valve. It is noteworthy that the volume of the charge from the crankcase breather system is fed omitting the MAF sensor. In this case it is possible to distort the

Table 1. Standardized diagnostic trouble codes directly or indirectly related to the malfunctioning EGR [13]

Tabela 1. Znormalizowane kody usterek bezpośrednio lub pośrednio związane z awaryjnym funkcjonowaniem układu EGR [13]

\begin{tabular}{|c|c|c|}
\hline DTC & $\begin{array}{c}\text { Circuit, system, parameter to which the error } \\
\text { code is related/ obwód, uktad, parametr, którego } \\
\text { dotyczy kod usterki }\end{array}$ & $\begin{array}{l}\text { Type of malfunction/rodzaj } \\
\text { usterki }\end{array}$ \\
\hline P0400 & $\begin{array}{l}\text { Exhaust gas recirculation flow/uktad recyrkulacji } \\
\text { spalin }\end{array}$ & $\begin{array}{l}\text { Malfunction/wadliwe } \\
\text { działanie }\end{array}$ \\
\hline P0401 & $\begin{array}{l}\text { Exhaust gas recirculation flow/układ recyrkulacji } \\
\text { spalin }\end{array}$ & $\begin{array}{l}\text { Insufficient detected/za maty } \\
\text { stopień recyrkulacji }\end{array}$ \\
\hline P0402 & $\begin{array}{l}\text { Exhaust gas recirculation flow/układ recyrkulacji } \\
\text { spalin }\end{array}$ & $\begin{array}{l}\text { Excesive detected/za duży } \\
\text { stopień recyrkulacji }\end{array}$ \\
\hline P0403 & $\begin{array}{c}\text { Exhaust gas recirculation circuit (valve or con- } \\
\text { trol)/uktad recyrkulacji spalin (zawór } \\
\text { lub sterowanie) }\end{array}$ & $\begin{array}{l}\text { Malfunction/wadliwe } \\
\text { działanie }\end{array}$ \\
\hline P0404 & $\begin{array}{l}\text { Exhaust gas recirculation circuit/układ } \\
\text { recyrkulacji spalin }\end{array}$ & $\begin{array}{l}\text { Range/performance/ } \\
\text { nieprawidtowy zakres } \\
\text { sygnatu }\end{array}$ \\
\hline P0405 & $\begin{array}{l}\text { Exhaust gas recirculation sensor A/układ } \\
\text { recyrkulacji spalin Obwód czujnika A }\end{array}$ & $\begin{array}{c}\text { Circuit low/za niska wartość } \\
\text { sygnału }\end{array}$ \\
\hline P0406 & $\begin{array}{l}\text { Exhaust gas recirculation sensor A/uktad } \\
\text { recyrkulacji spalin. Obwód czujnika A }\end{array}$ & $\begin{array}{l}\text { Circuit high/za wysoka } \\
\text { wartość sygnatu }\end{array}$ \\
\hline P0407 & $\begin{array}{l}\text { Exhaust gas recirculation sensor } \mathrm{B} / \text { uktad } \\
\text { recyrkulacji spalin. Obwód czujnika } B\end{array}$ & $\begin{array}{c}\text { Circuit low/za niska wartość } \\
\text { sygnału }\end{array}$ \\
\hline P0408 & $\begin{array}{l}\text { Exhaust gas recirculation sensor B/uktad } \\
\text { recyrkulacji spalin. Obwód czujnika B }\end{array}$ & $\begin{array}{l}\text { Circuit high/za wysoka } \\
\text { wartość sygnatu }\end{array}$ \\
\hline P0100 & $\begin{array}{l}\text { Mass or volume air flow/obwód masowego } \\
\text { lub objętościowego przeplywomierza powietrza }\end{array}$ & $\begin{array}{l}\text { Circuit malfunction/wadliwe } \\
\text { dzialanie }\end{array}$ \\
\hline P0101 & $\begin{array}{l}\text { Mass or volume air flow/obwód masowego } \\
\text { lub objętościowego przeplywomierza powietrza }\end{array}$ & $\begin{array}{l}\text { Circuit range performance } \\
\text { problem/nieprawidłowy } \\
\text { zakres wartości sygnatu }\end{array}$ \\
\hline P0102 & $\begin{array}{l}\text { Mass or volume air flow/obwód masowego } \\
\text { lub objętościowego przeplywomierza powietrza }\end{array}$ & $\begin{array}{c}\text { Circuit low input/za niska } \\
\text { wartość sygnatu wejściowego }\end{array}$ \\
\hline P0103 & $\begin{array}{l}\text { Mass or volume air flow/obwód masowego } \\
\text { lub objętościowego przeptywomierza powietrza }\end{array}$ & $\begin{array}{c}\text { Circuit high input/za wysoka } \\
\text { wartość sygnatu }\end{array}$ \\
\hline P0104 & $\begin{array}{l}\text { Mass or volume air flow/obwód masowego } \\
\text { lub objętościowego przeptywomierza powietrza }\end{array}$ & $\begin{array}{l}\text { Circuit intermittent/sygnat } \\
\text { elektryczny przerywany } \\
\text { sporadycznie }\end{array}$ \\
\hline
\end{tabular}

wadliwa praca elementów układów powoduje zapalenie kontrolki MIL (Malfunction Indicator Light) [12].

Zestawienie znormalizowanych kodów usterek bezpośrednio lub pośrednio związanych z awaryjnym funkcjonowaniem układu EGR zamieszczono w tabeli 1.

Ponadto niekiedy występujące kody błędów P0100 do P0104 oprócz wykazanych w tabeli 1 mogą stanowić informację pomocniczą w procesie oceny układu EGR, wykazując nieprawidłową wartość stopnia recyrkulacji. Zapisywane numery kodów usterek z grupy P0110 do P0114 przypisane są do obwodu czujnika temperatury powietrza na wejściu do układu dolotowego. Zwykle problematyczny w procesie lokalizacji uszkodzeń jest efekt równoczesnego zapisu błędu w obwodzie czujnika ciśnienia turbosprężarki z grupy P0235 do P0242, uzupełniony błędem obwodu czujnika temperatury recyrkulowanych spalin - z grupy P0544 do P0549.

Monitor diagnostyczny zawiera procedury diagnostyczne odpowiedzialne za kontrolę i obserwację przypisanych mu podzespołów. Zgodnie z zasadami OBD każdy sterownik pojazdu wykazuje implementację przynajmniej jednej procedury kontrolnej tworzącej monitory ciągłe lub nieciągłe. Producenci silników zobowiązani są do opublikowania algorytmu pozwalającego zrealizować cykl jezdny gwarantujący wykonanie wszystkich przewidzianych normą monitorów EOBD/ OBD II [9].

\section{Diagnostyka układu EGR z wykorzystaniem testera diagnostycznego}

Przedmiotem analiz obejmujących identyfikację uszkodzeń w układzie EGR jest układ dolotowy silnika DURATORQ TDCi, samochodu FORD MONDEO MK4 z układem wtrysku paliwa Common Rail Siemens. Układ dolotowy wyposażony jest w turbosprężarkę o zmiennej geometrii kanałów wlotowych spalin do turbiny oraz w chłodnicę powietrza wlotowego. Sterownik ECU - J248 steruje silnikiem krokowym pozycjonując przemieszczenie grzybka zaworu układu EGR. Należy zauważyć, iż objętość ładunku z odpowietrznika skrzyni korbowej dostarczana jest $\mathrm{z}$ pominięciem przepływomierza. Możliwe jest w tym przypadku zaburzenie stopnia recyrkulacji, zwłaszcza przy znacznym udziale przedmuchów spalin do skrzyni korbowej.

Proces identyfikacji uszkodzeń jest znacząco utrudniony $\mathrm{w}$ przypadku pojawiających się krótkotrwałych stanów niesprawności w nieregularnych odstępach i warunkach eksploatacji pojazdu. W opisywanej procedurze diagnostycznej pojazdu stwierdzono chwilowe i sporadyczne spadki mocy połączone z brakiem płynności 
recirculation rate particularly if the blow-by to the crankcase is extensive.

The process of fault identification is getting difficult if intermittent malfunctions occur at irregular intervals and unsteady engine operating states. In the described diagnostic procedure of the vehicle momentary and sporadic power drops were observed combined with a lack of smoothness in acceleration and high exhaust opacity. The use of a variety of scan tools and other diagnostic devices significantly accelerates the diagnostic process. In the case of a short-term malfunction the ECU does not interpret the existing parameters as erratic, and does not store the error in the memory.

Upon connecting of the diagnostic interface of the TEXA Nawigator TXT (Fig. 1) scan tool to the vehicle no error codes stored in the memory were detected. The analysis of the parameters pulled from the ECU and those given by the manufacturer did not show any deviations from the required values.

Analogically to the EGR test procedures, according to DeltaScan, assuming the basic settings [04] in the group of measurement blocks [003] an observation was made as the engine speed was increased above $1400 \mathrm{rpm}$. The tester then provided a two-state value of the parameter storage that identified the request of the EGR valve opening or closing given by the controller. Another parameter shown in this group of measurement blocks is the current signal of the mass airflow determined by the MAF sensor. An important parameter is the percentage value of the filling coefficient of the PWM signal confirming the setting of the EGR valve stepper motor. In the analyzed system, when the valve was closed the value of the filling coefficient did not deviate from the admissible level i.e. above $70 \%$ and when the valve was open the value was also in the $25 \%$ limit. In the measure-

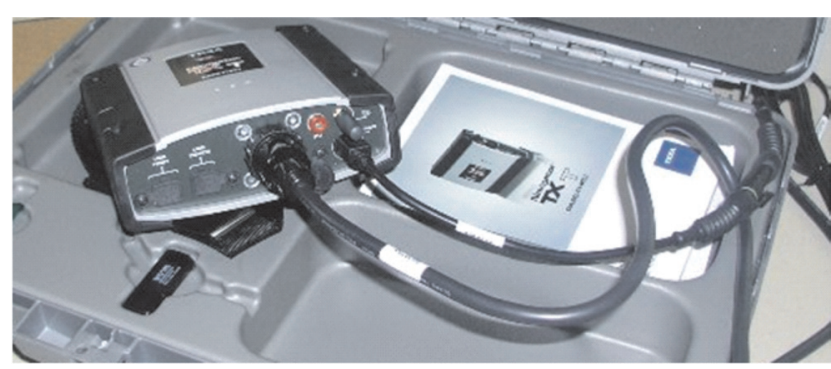

Fig. 1. TEXA Nawigator TXT scan tool Rys. 1. Tester TEXA Nawigator TXT

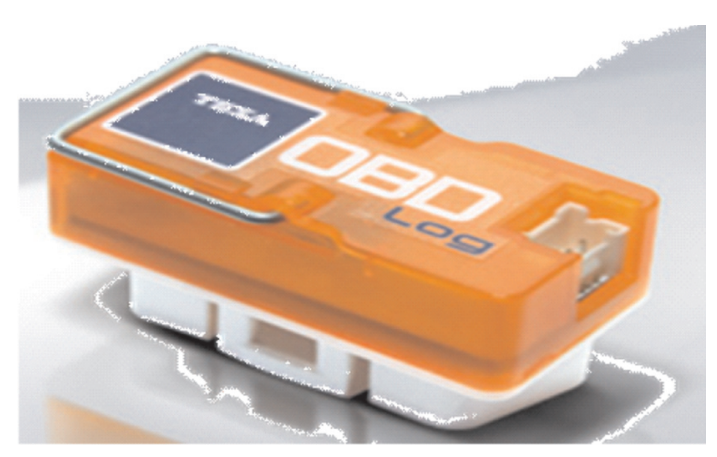

Fig. 2. TEXA OBD-Log recorder Rys. 2. Rejestrator TEXA OBD-Log przyspieszania oraz znacznym zadymianiem spalin. Wykorzystanie różnego rodzaju skanerów diagnostycznych i diagnoskopów w sposób znaczący przyspiesza proces diagnostyczny. W przypadku krótkotrwałego występowania usterki sterownik ECU nie interpretuje zaistniałych parametrów jako błędnych i tym samym nie zapisuje usterki w pamięci sterownika.

Po podłączeniu interfejsu diagnostycznego testera, TEXA Nawigator TXT (rys. 1) nie odnotowano żadnego błędu w pamięci kodów usterek sterownika ECU. Analiza odczytanych i podanych parametrów przez producenta silnika nie wykazała odstępstw od wymaganych wartości.

W analogii do procedur testu EGR wg programu DeltaScan, przyjmując ustawienia podstawowe [04] w grupie bloków pomiarowych [003] - wykonano obserwację przy zwiększeniu prędkości obrotowej silnika od około 1400 obr/min. Tester podaje wówczas dwustanową wartość zapisu parametrów, która identyfikuje wydanie przez sterownik ECU rozkazu otwarcia lub zamknięcia zaworu recyrkulacji spalin. Kolejnym parametrem wyświetlanym w tej grupie bloków pomiarowych jest aktualny sygnał masowego natężenia przepływu powietrza wyznaczony przez przetwornik MAF. Istotnym parametrem jest wyrażona w procentach wartość współczynnika wypełniania sygnału PWM, świadcząca o wysterowaniu silnika krokowego zaworu EGR. W analizowanym układzie przy zamkniętym zaworze EGR wartość współczynnika wypełnienia nie odbiegała od poziomu dopuszczalnego tj. powyżej $70 \%$, jak również przy otwartym zaworze wartość była prawidłowa, tzn. w granicach $25 \%$. W bloku pomiarowym zmieniały się również wskazania wartości masowego przepływu powietrza, które przy zamkniętym zaworze EGR zawierały się $\mathrm{w}$ wyznaczonym przedziale $\mathrm{tj}$. 420 do $600 \mathrm{mg} / \mathrm{cykl}$, oraz 180 do $340 \mathrm{mg} / \mathrm{cykl}$ - dla zaworu w pozycji otwartej.

Istotnym faktem, na który należy zwrócić uwagę jest przebieg zmian masowego natężenia przepływu powietrza, którego wartość powinna zmieniać się skokowo od momentu wysterowania zaworu EGR. Wydłużony czas oczekiwanej zmiany wartości przepływu powietrza może wskazywać na nadmierne zanieczyszczenie elementów wykonawczych zaworu EGR powodując opóźnienia w jego pozycjonowaniu. Brak reakcji zmiany masowego natężenia przepływu powietrza na zamykanie i otwieranie zaworu EGR może świadczyć również o wadliwym działaniu sensora MAF.

Biorąc pod uwagę okresowość pojawiania się chwilowych stanów niesprawności silnika i brak zapisanych kodów błędów zdecydowano się na zapis wybranych parametrów w trakcie przejazdów testowych z wykorzystaniem rejestratorem TEXA OBD Log ze standardowym przyłączem 16-pin do gniazda diagnostycznego OBDII J1962 przedstawionym na rysunku 2. Zapis podstawy czasu w rejestratorze ułatwienia analizę parametrów wraz z możliwością oceny stanu eksploatacyjnego silnika, przy którym została zapisana usterka.

Stan awaryjny zaznaczył się zapisem błędów dopiero po przeprowadzeniu cyklicznego wzrostu obciążenia silnika wg charakterystyk zapisanych na rys. 3. Analizując stanu krótkotrwałego spadku mocy i wzrostu zadymienia spalin przy 
ment block the values of the mass airflow changed as well and fell in the interval from 420 to $600 \mathrm{mg} /$ cycle when the EGR valve was closed and 180 to $340 \mathrm{mg} /$ cycle when the EGR valve was opened.

An important fact that has to be noted is the course of the changes of the mass airflow whose value should change stepwise from the moment of the setting of the EGR valve. An extended time of the expected change of the value in the mass airflow may indicate an excessive contamination of the actuators of the EGR valve leading to a delay in its positioning. No reaction of the air mass airflow to the opening and closing of the EGR valve may confirm a malfunction of the MAF sensor.

Due to the intermittence of the engine malfunctions and lack of error codes stored in the memory the authors decided record selected parameters during the test runs using the TEXA OBD Log recorder equipped with a standard 16-pin OBDII J1962 port as shown in Fig. 2. The recording of the time scale in the recorder facilitates the analysis of the parameters and enables the evaluation of the operating state at which the fault code was stored.

The state of malfunction was indicated by the storage of the error code in the memory only after a cyclic increase in the engine load as per the characteristics shown in Fig. 3. Analyzing the conditions of a short-term drop of power and an increase in the exhaust opacity at part loads we need to note that at this time a growth in the mass airflow and the charging pressure did not occur while the engine load was partly increased. When the symptoms of a momentary drop of power subsided the parameters stabilized i.e. at the engine load of $75 \%$ a clear increase in the mass airflow to the value of $69 \mathrm{gs}^{-1}$ and absolute charging pressure to the value of 230 $\mathrm{kPa}$ occurred. In the case of a cycling increase in the engine load the malfunction became more conspicuous leading to the occurrence of the error codes in the ECU and switching into restricted performance mode.

Analyzing the parameters of the test run as per Fig. 3 just before the recording of the malfunction by the controller we could observe too low a value of the mass airflow at a low value of the charging pressure and a hesitating engine operation. On this basis we may initially suspect a rather frequent malfunction of the EGR valve blocking in the position of partial opening. The reason for such a situation may be a momentary blocking of the turbocharger variable vanes.

In order to unambiguously determine the reasons for the malfunction the engine test was repeated using stationary scan tools identifying the error codes: P0402 and P0404 assigned to the EGR monitor. Incorrect diagnostics may have been directed towards a malfunctioning mass airflow meter. A frequent case of simplifying the diagnostic process is the replacement of the MAF, which in many cases provides a short-term improvement of the functional conditions of the engine. Introducing a MAF sensor of a proper level of the output signal most often eliminates the effect of error conjunction resulting mostly from an incomplete EGR valve opening. obciążeniach częściowych należy zauważyć, iż w tym czasie nie nastąpił wzrost wartości masowego natężenia przepływu powietrza oraz ciśnienia doładowania podczas częściowego zwiększania obciążenia silnika. Po ustapieniu objawów chwilowego spadku mocy silnika parametry stabilizowały się tj. przy obciążeniu silnika $75 \%$ następował wyraźny przyrost masowego przepływu powietrza do wartości $69 \mathrm{gs}^{-1}$ jak również wzrost bezwzględnego ciśnienia doładowania do wartości $230 \mathrm{kPa}$. W przypadku cyklicznego zwiększania obciążenia silnika nastąpiło nasilenie się objawów usterki prowadząc do zapisania kodów błędów przez sterownik ECU oraz przejście na awaryjny tryb pracy.

Analizując parametry przejazdu, wg rysunku 3, tuż przed zarejestrowaniem usterki przez sterownik można zaobserwować zbyt niską wartość masowego natężenia przepływu powietrza, przy niskiej wartości ciśnienia doładowania turbosprężarki oraz nierównomiernej praca silnika. Na tej podstawie można wnioskować wstępnie o wystąpieniu częstej usterki układu wynikającej z okresowego blokowania się zaworu EGR w pozycji częściowego otwarcia. Przyczyną takiego stanu może mieć również swoje podłoże w chwilowym zablokowaniu kierownic turbosprężarki.

W celu jednoznacznego ustalenia przyczyn usterki dokonano powtórnego testu silnika z wykorzystaniem podanych testerów stacjonarnych identyfikując zapisane kody usterek: P0402 i P0404 przypisane monitorowi EGR. Obszar błędnej decyzji mógł zostać ukierunkowany w tym przypadku również na potrzebę wymiany masowego przepływomierza powietrza. Częstym przypadkiem uproszczeń procesu diagnostycznego jest wymiana przepływomierza masowego powietrza, co w wielu przypadkach przynosi chwilową poprawę stanu funkcjonalnego silnika. Wprowa-

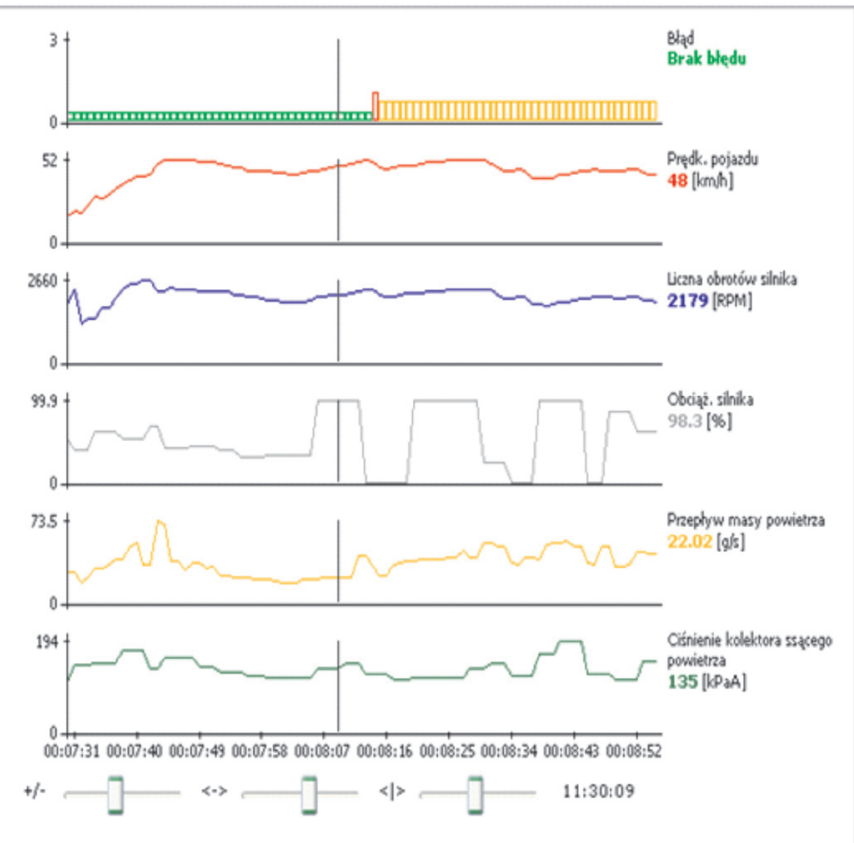

Fig. 3. The parameters of the TEXA OBD Log recorder with the error codes $\mathrm{P} 0402$ and $\mathrm{P} 0404$ stored

Rys. 3. Parametry rejestratora TEXA OBD Log z zarejestrowanym błędami P0402 i P0404 
The intensity of the EGR system malfunctions in modern diesel engines and a frequent renewals of the EGR systems at the dealership workshops indicates a need to conduct research on the underlying reasons. The main problem pertains to engines previously operated on diesel fuel and subsequently switched to fuel containing biocomponents on the level of $5.75 \%$.

The reasons for the malfunction of EGR systems were also related with the evaluation of the influence of biocomponent-based diesel fuel application on the process of deposit formation in the EGR system of a diesel engine. The research comprised an evaluation of the content of the precipitated unoxidized organic compounds. Analyses of the compositions of the deposits in the EGR ducts were performed for two DURATORQ TDCi engines of the mileage of $80.000 \mathrm{~km}$ as per the CEC F-20-98 procedure. A comparative analysis of the issue of deposit formation in the EGR system was possible due to the fact that a variety of fuels were used: diesel fuel (Ekodiesel Ultra) and B10 (containing biocomponents). At a growing share of the FAME content in diesel fuel [2], these become actual in-service problems of the users of modern diesel engines.

\section{Spectral analysis of the deposits in the EGR valve zone}

A spectral analysis was performed of the deposits sampled in the surface of the EGR channel in the DURATORQ TDCi engines fueled with B10 biofuel and Ekodiesel Ultra (diesel fuel). In the microscopic analysis of the deposit (enlarged 100x) from the engine fueled exclusively with Ekodiesel Ultra grains of deposits were observed that were bonded with a tarry substance. The deposits on the EGR valve of the engine fueled with B10 biofuel had a more refined and dry structure with a visible fraction of mineral material. The comparison of the deposit zones for two EGR valves controlling the exhaust flow - the one disassembled from a vehicle and a brand new one have been shown in Figure 4. The valve head and the seat did not show any signs of damage resulting from excess exhaust temperature, which usually take place at an excessive backpressure of the exhaust gas.

The spectrums of the X-ray fluorescence with the XRF ED energy dispersion were recorded with the ED 2000 recorder made by Oxford Instruments, while the IR infrared spectrums (FTIR) were recorded with FTS 175 by BIO-RAD.

In the qualitative analysis the authors used a method of X-ray XRF taking a sample of a deposit after cleaning of the EGR zone with hexan. The recording of the XRF characteristics for deposits taken from the EGR valve zone of an engine fueled with Ekodiesel Ultra and B10 have been shown in Fig. 5. Based on the assessment of the changes of the intensity of the spectral bands for the identified elements a qualitative analysis was performed. In the analyzed deposits such metals were identified as: iron, zinc, chromium, nickel and copper. Other elements were also present in the analyzed composition- calcium, phosphorus and sulfur. Iron traces originate in the processes of corrosion or may be an environmental contaminant while chromium, nickel and copper indicate a dzenie przepływomierza powietrza o właściwym poziomie sygnału wyjściowego usuwa zwykle doraźnie efekt koniunkcji błędów najczęściej wynikających z niepełnego otwarcia zaworu EGR.

Intensywność uszkodzeń układów EGR stosowanych w silnikach o ZS i ich częsta wymiana w ASO wskazuje na potrzebę prowadzenia badań nad przyczynami tego stanu. Główny problem dotyczy pojazdów eksploatowanych uprzednio na ON i przejściu na obecne warunki zasilania paliwami z udziałem biokomponentów na poziomie 5,75\%.

Ustalenie przyczyn niesprawności układu EGR, zostało ukierunkowane również na ocenę wpływu stosowania $\mathrm{ON} \mathrm{z}$ udziałem biokomponentów na proces tworzenia się osadów w układzie EGR silnika o ZS. Wnioskowanie obejmowało ocenę zawartości wytrąconych nieutlenionych składników pochodzenia organicznego. Przeprowadzono analizy składu osadów w strefie kanału przelotowego EGR dla dwóch silników DURATORQ TDCi po przebiegu eksploatacyjnym 80 tys.km wg procedury CEC F-20-98. Analizę porównawczą zagadnień powstawania osadów w układzie EGR umożliwił proces zasilania odrębnymi paliwami tj. olejem napędowym Ekodiesel Ultra oraz paliwem B10 z udziałem biokomponentów. Zagadnienia te przekładają się na zasadniczą problematykę eksploatacyjną użytkowników współczesnych silników o ZS przy postępującym wzroście procentowego udziału dodatków FAME do ON [2].

\section{Analiza spektralna osadów zalegających strefę zaworu EGR}

Przeprowadzono analizę spektralną osadów pobranych z powierzchni kanału przelotowego zaworu EGR z kanału przepływu powietrza silników DURATORQ TDCi, zasilanych biopaliwem B10 i olejem napędowym Ekodiesel Ultra. W analizie mikroskopowej osadu (pow. 100x) pochodzącego z silnika samochodu zasilanego wyłącznie olejem napędowym Ekodiesel Ultra zauważono ziarna osadu, które zostały sklejone smolistą substancją. Osad na zaworze EGR silnika zasilanego paliwem B10 cechował się strukturą bardziej drobnoziarnistą i ,suchą" z widoczną frakcja materiału mineralnego. Porównanie strefy osadów dla zaworu sterującego przepustem spalin zaworu EGR fabrycznie nowego oraz w stanie zdemontowanym z badanego silnika przedstawia rysunek 4. Grzybek i gniazdo zaworu nie wykazywało stanu uszkodzeń spowodowanych nadmierną temperaturą spalin, co zwykle ma miejsce przy zbyt wysokim przeciwciśnieniu spalin.

Widma fluorescencji rentgenowskiej z dyspersją energii XRF ED zapisano rejestratorem ED 2000 firmy Oxford Instruments, natomiast widma $\mathrm{w}$ podczerwieni IR (FTIR) zarejestrowano na FTS 175 firmy BIO-RAD.

W analizie jakościowej posłużono się metodą fluorescencji rentgenowskiej XRF pobierając próbkę osadów po przemyciu strefy kanału EGR heksanem. Zapis charakterystyk XRF dla osadów pobranych ze strefy zaworu EGR silnika zasilanego paliwem Ekodiesel Ultra. i B10 przedstawiono na rysunku 5. Na podstawie oceny zmian intensywności pasm dla zidentyfikowanych pierwiastków dokonano oceny jakościowej osadów. $\mathrm{W}$ badanych osadach stwierdzono obecność głównie metali 

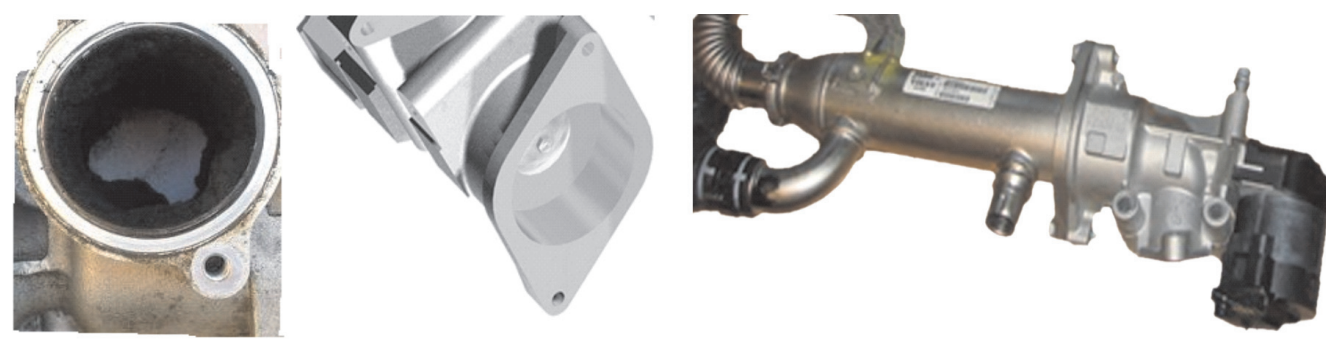

Fig. 4. The deposits on the inner surface of the EGR channel in the DURATORQ TDCi engine fitted in FORD MONDEO MK4 143 HP for the condition of malfunction (a) and a brand new valve (b). A set of connecting components for the exhaust cooler (c)

Rys. 4. Osady na powierzchni wewnętrznej kanału króćca EGR silnika DURATORQ TDCi, FORD MONDEO MK4 143 PS dla stanu eksploatacyjnego wystapienia kodu usterki (a), oraz zaworu fabrycznie nowego (b). Zestaw elementów przyłączeniowych do chłodnicy spalin (c)

friction wear of the engine friction pairs. The presence of zinc, calcium and phosphorus results from the degradation of the engine lubricant, including the oil additives. Besides, depresators as part of the biofuel conditioners contain ions of iron [3]. In the XRF spectrum of the deposits for the engine fueled with B10 greater intensity of the iron spectrum was observed. These contaminants results mainly from the processes of corrosion of steel elements whose structure is more prone to FAME related corrosion. We should note a relatively high intensity of the spectral bands of calcium and zinc, which indicates contamination with engine lubricant and a share of a spectral band confirming the presence of nickel. The effect that distorts the spectral analysis is the share of fractions coming from the oil emulsion directed from the engine breather system.

Upon taking the deposit off the inner walls of the EGR valve with chloroform the samples were analyzed in the infrared spectrum. Traces of fuel, engine oil and the products of their degradation were observed. The IR spectrum for the substances in the EGR zone for the vehicle fueled with diesel fuel is poorer-Figs. 6 and 7. In the beginning a comparative analysis was performed of the spectral bands characteristic of hydrocarbons i.e. wave number: $2850 \mathrm{~cm}^{-1}$

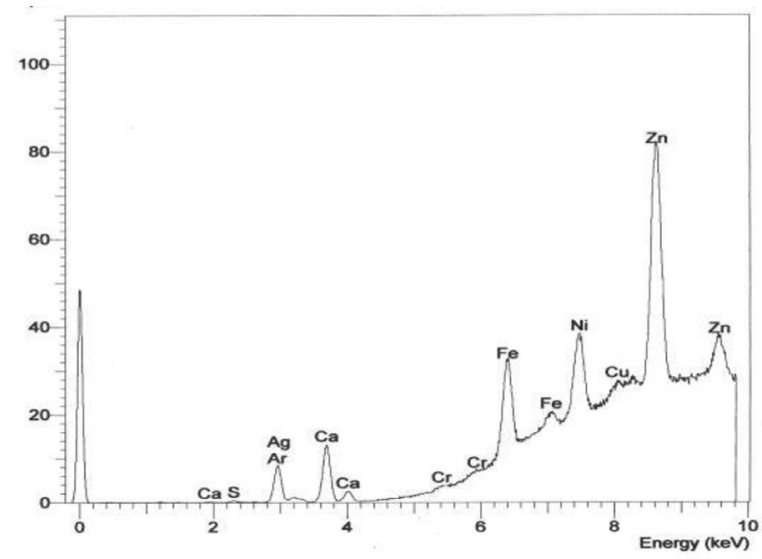

Fig. 5. The XRF spectrum for the deposits taken from the EGR valve zone of an engine fueled with Ekodiesel Ultra

Rys. 5. Widmo XRF dla osadów ze pobranych ze strefy zaworu EGR silnika zasilanego paliwem Ekodiesel Ultra

\section{dacji oleju silnikowego,}

takich jak: żelazo, cynk, chrom, nikiel, miedź. Ponadto zwrócono uwagę na obecność takich pierwiastków jak wapń oraz fosfor i siarka. Żelazo pochodzi z procesów korozji lub też może być zanieczyszczeniem środowiskowym - natomiast chrom, nikiel i miedź świadczą o zużyciu ciernym elementów roboczych silnika. Obecność cynku, wapnia i fosforu wynika z degraw tym również pakietu dodatków uszlachetniających. Ponadto depresatory jako składniki pakietu dodatków do biopaliw zawierają jony żelaza [3]. W widmie XRF osadów dla silnika samochodu zasilanego B10 zarejestrowano wyższą intensywność pasm żelaza. Zanieczyszczenia te wynikają głownie z procesów korozji elementów stalowych, których struktura jest bardziej podatna na działanie korozyjne FAME. Należy zauważyć, względnie wysoką intensywność pasm wapnia i cynku, co wskazuje na zanieczyszczenia olejem silnikowym oraz udział pasma świadczącego o występowaniu niklu. Efektem zakłócającym analizę widmową jest udział frakcji pochodzących z emulsji olejowej kierowanej z odmy silnika.

Po wymyciu chloroformem osadu $\mathrm{z}$ wewnętrznej powierzchni zaworu EGR poddano analizie próbki w widmie podczerwieni. Zaobserwowano zarówno pozostałość paliwa jak również oleju silnikowego oraz produkty ich degradacji. Widmo IR dla substancji wydzielonych w strefie EGR w przypadku samochodu zasilanego ON jest uboższe - rysunek 6 i 7. Na wstępie dokonano analizy porównawczej pasm

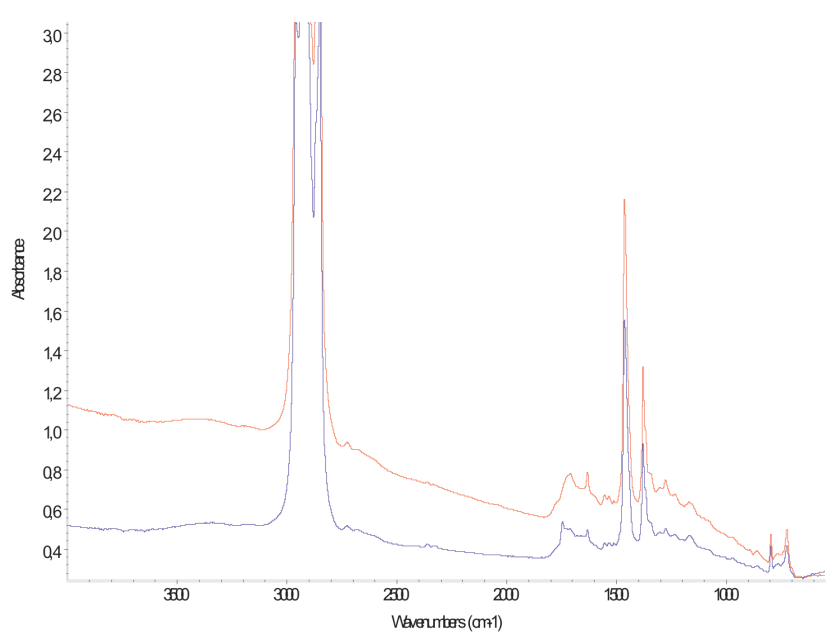

Fig. 6. IR spectrum (range $4000 \mathrm{~cm}^{-1}-900 \mathrm{~cm}^{-1}$ ) of the soluble fraction of the deposit from the EGR valve zone in the engines fueled with the analyzed fuels - diesel oil (red) and B10 (blue).

Rys. 6. Widmo w podczerwieni (zakres $4000 \mathrm{~cm}^{-1}-900 \mathrm{~cm}^{-1}$ ) części rozpuszczalnej osadu ze strefy zaworu EGR silników samochodów napędzanych badanymi paliwami ON (czerwony) i i B10 (niebieski). 
$-3000 \mathrm{~cm}^{-1}, 1464 \mathrm{~cm}^{-1}, 1377 \mathrm{~cm}^{-1}, 722 \mathrm{~cm}^{-1}$ ) [10]. In both cases greater background intensification occurred, which indicates the presence of soot. Additionally, spectral bands are present of vibration typical of hydroxyl group bonds (approx. $3400 \mathrm{~cm}^{-1}$ ) that may come from the adsorbed water and may be a derivative of the alcohol structure and carboxylic acids [10].

The most intense is the spectral band of approx. 1655 $\mathrm{cm}^{-1}$ in the diagnostic area of $2000 \mathrm{~cm}^{-1}-1600 \mathrm{~cm}^{-1}$ confirming the occurrence of processes of oxidation of organic compounds to carbonyl and carboxyl structures. The effect of the influence of these compounds on the nitric oxides is most likely related to the presence of the hydrated salts of carboxylic acids. These substances may also come from the processes of oxidation and degradation of alkaline additives present in the engine lubricant.

The spectral band, approx. $1630 \mathrm{~cm}^{-1}$ comes from other compounds having C-O- $-\mathrm{NO}_{2}$ bonds created as a result of nitro oxidation of the components of the engine lubricant and fuel with nitric oxides. As for the case of substances identified in the deposits coming from the EGR systems of the engine fueled with B10 the spectrum is richer. We may observe an intense spectral band of $1747 \mathrm{~cm}^{-1}$ related to the presence of esters. We cannot unambiguously state whether these are undegraded FAME esters or the products of their degradation or di or trimerization.

For the purpose of identification of the deposits of the ester group the relations of the carbonyl groups $\mathrm{C}=\mathrm{O}$ (aliphatic) are representative with the corresponding spectral band in the wave number of $1750-1735 \mathrm{~cm}^{-1}$.

The presence of the ester structures is confirmed by the spectral bands in the „finger print” range (approx. 1240 $\mathrm{cm}^{-1}$ and $1160 \mathrm{~cm}^{-1}$ ). The spectral band of approx. 1720 $\mathrm{cm}^{-1}$ comes from other carbonyl or carboxyl compounds while the spectral band of approx. $1633 \mathrm{~cm}^{-1}$ indicates the

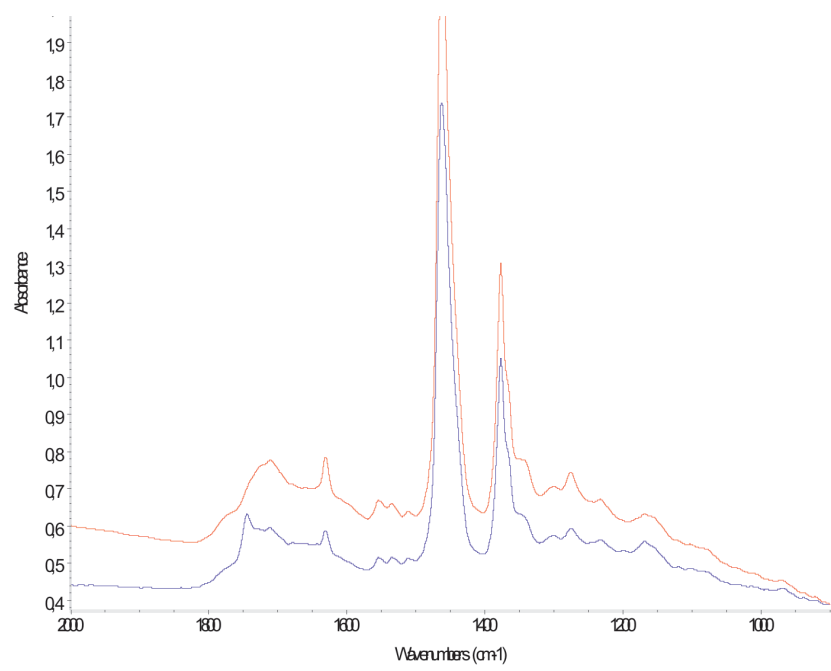

Fig. 7. IR spectrum (range $2000 \mathrm{~cm}^{-1}-900 \mathrm{~cm}^{-1}$ ) of the soluble fraction of the deposit from the EGR valve zone in the engines fueled with the analyzed fuels - diesel oil (red) and B10 (blue)

Rys. 7. Widmo w podczerwieni (zakres $2000 \mathrm{~cm}^{-1}-900 \mathrm{~cm}^{-1}$ ) czéści rozpuszczalnej osadu ze strefy zaworu EGR silników samochodów napędzanych badanymi paliwami ON (czerwony) i i B10 (niebieski) charakterystycznych dla węglowodorów tj. zakres liczby falowej: $2850 \mathrm{~cm}^{-1}-3000 \mathrm{~cm}^{-1}, 1464 \mathrm{~cm}^{-1}, 1377 \mathrm{~cm}^{-1}$, $722 \mathrm{~cm}^{-1}$ ) [10]. W obu przypadkach wystąpiło silniejsze podniesienie tła co wykazuje związek z obecnością sadzy. Dodatkowo obecne są pasma drgań typowe dla wiązań grup hydroksylowych (ok. $3400 \mathrm{~cm}^{-1}$ ) mogące pochodzić od zasorbowanej wody jak również mogą stanowić pochodną struktur alkoholi i kwasów karboksylowych [10].

Najbardziej intensywne jest pasmo ok. $1655 \mathrm{~cm}^{-1} \mathrm{w}$ obszarze diagnostycznym $2000 \mathrm{~cm}^{-1}-1600 \mathrm{~cm}^{-1}$ świadczące o występowaniu procesów utleniania związków organicznych do struktur karbonylowych i karboksylowych. Efektem oddziaływaniem tych związków na tlenki azotu związane jest prawdopodobnie z obecnością uwodnionych soli kwasów karboksylowych. Substancje te mogą również pochodzić z procesów utleniania i degradacji dodatków zasadowych obecnych w oleju silnikowym.

Pasmo ok. $1630 \mathrm{~cm}^{-1}$ pochodzi od innych związków zawierających wiązania $\mathrm{C}-\mathrm{O}-\mathrm{NO}_{2}$, powstałych w wyniku nitrooksydacji składników oleju silnikowego i paliwa tlenkami azotu. W przypadku substancji wydzielonej z osadu pochodzących z układu EGR silnika samochodu zasilanego B10 - widmo IR jest bogatsze. Obserwuje się intensywne pasmo $1747 \mathrm{~cm}^{-1}$ związane z obecnością estrów. Nie można jednoznacznie stwierdzić, czy są to niezdegradowane estry FAME, czy produkty ich degradacji lub di- i trimeryzacji.

Dla potrzeb identyfikacji osadów grupy estrowej reprezentatywne są relacje grup karbonylowych $\mathrm{C}=\mathrm{O}$ (alifatyczne) $\mathrm{z}$ odpowiadającym im pasmem $\mathrm{w}$ obszarze liczby falowej $1750-1735 \mathrm{~cm}^{-1}$.

Obecność struktur estrowych potwierdzają pasma w zakresie, ,finger print" (ok. $1240 \mathrm{~cm}^{-1}$ i $1160 \mathrm{~cm}^{-1}$ ). Pasmo ok. $1720 \mathrm{~cm}^{-1}$ pochodzi od innych związków karbonylowych lub karboksylowych, natomiast pasmo ok. $1633 \mathrm{~cm}^{-1}$ wskazuje na obecność produktów oddziaływania tlenków azotu z produktami utlenienia paliwa. Słabe pasmo ok. 1735 $\mathrm{cm}^{-1}$ pochodzi od innych związków zawierających wiązania $\mathrm{C}=\mathrm{O}$, powstałych $\mathrm{w}$ wyniku utleniania składników oleju silnikowego i paliwa. Identyfikacja grupy kwasów karboksylowych jest zwykle problematyczna, gdyż rejestrowane są one w szerokim paśmie O-H (rozciągające), które nakłada się z pasmem C-H (rozciągające). Powodem występowania szerokiego pasma O-H w kwasach karboskylowych jest to, że często kwasy te występują w postaci dimerów połączonych wiązaniem wodorowym [10]. Absorpcja rozciągającego $\mathrm{C}-\mathrm{O}$ pojawia się $\mathrm{w}$ zakresie $1300-1210 \mathrm{~cm}^{-1}$, natomiast strefy zginające O-H występują w obszarze liczby falowej $1440-1395 \mathrm{~cm}^{-1}$ oraz $950-910 \mathrm{~cm}^{-1}$.

\section{Wnioski}

1. Zasadniczy problem decyzji diagnostycznej występuje wraz z potrzebą rozpoznania złożonych przyczyn usterek analizowanego układu zapisanych w wykazie błędów.

2. Zaprezentowane etapy testów wraz z analizą zapisanych błędów układu ukierunkowują procedurę wnioskowania na podjęcie trafnej decyzji diagnostycznej.

3. Analizy widma fluorescencji rentgenowskiej z dyspersją energii w odniesieniu do wyznaczenia udziału pierwi- 
presence of the products of reactions between the nitric oxides and the products of fuel oxidation. A poor spectral band of approx. $1735 \mathrm{~cm}^{-1}$ comes from other compounds having the bonds $\mathrm{C}=\mathrm{O}$ generated as a result of oxidation of the components of the engine oil and fuel. The identification of the group of carboxylic acids is usually problematic as they are recorded in a wide spectral band of O-H (extending) that overlap with the spectral band of $\mathrm{C}-\mathrm{H}$ (extending). The reason or the occurrence of a wide spectral band of $\mathrm{O}-\mathrm{H}$ in the carboxylic acids is the fact that these acids often appear in the form of dimers connected with a hydrogen bond [10]. The absorption of the extending $\mathrm{C}-\mathrm{O}$ appear in the range of $1300-1210 \mathrm{~cm}^{-1}$, and the bending zones $\mathrm{O}-\mathrm{H}$ appear in the area of the wave number of $1440-1395 \mathrm{~cm}^{-1}$ and $950-910 \mathrm{~cm}^{-1}$.

\section{Conclusions}

1. The fundamental problem of a diagnostic analysis appears in the need to explore complex phenomena of stored malfunctions of the analyzed system.

2. The presented stages of the tests together with the analysis of the stored error codes of the system lead to a correct diagnostic decision.

3. The spectral analyses of the X-ray fluorescence with energy dispersion in relation to the determination of the share of the chemical elements forming the deposit in the EGR valve zone as well as the recording of the IR spectrum made after the extraction of the sample have confirmed a share of organic compounds in the solid deposit.

4. The main sources of the deposit are FAME polymer groups coming from varied biofuel conditioners.

5. The presence of deposits leads to a blocking of the control elements of the exhaust gas flow through the EGR valve and, as a consequence occurrence of a DTC stored in the OBD system.

\section{Nomenclature/Skróty i oznaczenia}

B10 mieszanina 10\% (V/V) FAME i 90\% (V/V) ON

DPF Diesel Particulate Filter/filtr czastek statych

EGR Exhaust Gas Recirculation/recyrkulacja spalin

FAME Fatty Acid Methyl Esters/estry metylowe kwasów tluszczowych

MAF Mass Airflow Sensor/masowy przepływomierz powietrza

$\mathrm{NO}_{\mathrm{x}} \quad$ Nitric Oxides/tlenki azotu

ON diesel fuel/olej napędowy

PM Particulate Matter/czastki state

$\mathrm{X}_{\mathrm{EGR}}$ exhaust recirculation rate/stopień recyrkulacji spalin

Professor Bogusław Cieślikowski, DSc., DEng. - Faculty of Production Engineering and Energy Production, Krakow University o Agriculture. Prof. dr hab. inż. Bogustaw Cieślikowski - UR Kraków, Wydz. Inżynierii Produkcji i Energetyki. e-mail: boguslaw.cieslikowski@ur.krakow.pl

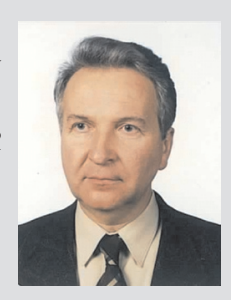

astków tworzących osad w strefie zaworu EGR jak również zapis widma spektroskopii w podczerwieni wykonany po ekstrakcji próbki wykazały udział związków organicznych w osadzie stałym.

4. Głównym źródłem osadu są grupy polimerów FAME pochodzące ze zróżnicowanych pakietów uszlachetniających stosowanych do produkcji biopaliw.

5. Zaleganie osadów prowadzi do zablokowania elementów sterujących przepustem spalin zaworu EGR i w konsekwencji do zaistnienia błędu zapisanego w systemie OBD.

\section{Bibliography/Literatura}

[1] Bieniek A., Graba M., Lechowicz A:. Adaptive Control Of Exhaust Gas Recirculation at Nonroad Vehicle Diesel Engine, Journal of KONES 2011 vol. 18, No. 4, pp. 11.

[2] Cieślikowski B.: Monitorowanie układu EGR silnika TDI, Technika, Eksploatacja ,Systemy Transportowe - Autobusy 10/2011 ISSN 1509-5878.

[3] Cieślikowski B.: Spectral analysis of deposits from a catalytic converter of Diesel engine. Kongres: Combu stion Engines. Wyd. Silniki spalinowe. PTNSS 3/2011(146), 1-6.

[4] Cieślikowski B., Jakóbiec J.: Modyfikacja właściwości użytkowych biopaliw w aspekcie zagadnień eksploatacyjnych pojazdów rolniczych.. Inżynieria Rolnicza, Nr 19 (88), 2010.

[5] Jung S. Ishida M., Yamamoto S., Ueki H., Sakaguchi D., Enhancement of $\mathrm{NO}_{\mathrm{x}}$ - PM trade off a diesel engine adopting bio-ethanol and EGR. International Journal of Automotive Technology, Vol. 11, No. 5 pp. 611-611. 2010.

[6] Lejda K., 2000. Elimination of $\mathrm{NO}_{\mathrm{x}}$ Emission In Diesel Engine by EGR Metod, Western Scientific Centra of Ukrainian Transport Academy, Logos 2000.

[7] Merkisz J., Mazurek S.: Pokładowe systemy diagnostyczne pojazdów. WKiŁ Warszawa, ISBN 978-83-206-1633-0, s 226-319, 2007.

[8] PN-EN 14214: Paliwa do pojazdów samochodowych. Estry metylowe kwasów thuszczowych (FAME) do silników o zapłonie samoczynnym (Diesla). Wymagania i metody.

[9] Rokosz U.: Układy oczyszczania spalin i pokładowe systemy diagnostyczne samochodów WKi Ł Warszawa 2007.

[10] Sadlej J.: Spektroskopia molekularna. Wydawnictwa Naukowo Techniczne, Warszawa, 2002.

[11] Yokomura H., Kohketsu S., Mori K., EGR Systems In a Turbocharged and Intercooled Heavy-Duty Diesel Engine Expansion of EGR Area with Venturi EGR System, Technical Review, 2003.

[12] White Ch., Randall M.: Kody usterek. WKit, ISBN 978-83208-1591-3, s. 78-95, Warszawa 2008.

[13] Wypis z norm: SAE J2012 i ISO 15 031-6.

Professor Janusz Jakóbiec, DSc., DEng. - Faculty of Energy and Fuels, AGH University of Science and Technology, Krakow.

Prof. nadzw. dr hab. inż. Janusz Jakóbiec - AGH Kraków, Wydziat Energii i Paliw.

e-mail:jjakobie@agh.edu.pl 